\author{
Joanna Zwierzchowska ${ }^{1}$ \\ University of Warsaw - Faculty of Geography and Regional Studies \\ - Institute of Global and Regional Studies \\ 00-927 Warsaw, Krakowskie Przedmieście 30 \\ e-mail: j.k.zwierzchowska@gmail.com
}

\title{
TOURISM IN RURAL AREAS OF CASTILLA-LA MANCHA
}

\begin{abstract}
The rural areas of Castilla-La Mancha have managed to preserve a unique natural and cultural character. A great diversity of touristic qualities makes the region especially attractive for development of rural tourism.

For many years, the autonomous community of Castilla-La Mancha had to cope with numerous socio-economic difficulties. Development of the tourist industry resulted in diversification of income sources and higher level of employment. Another positive effect of the process was activation of female members of the community. The principle aim of this article is to underline the complementary role of tourism in rural areas in relation to agriculture and urban tourism.
\end{abstract}

Key words: Rural tourism, Castilla La-Mancha, Spain, rural area, rural accommodation.

The rural tourism movement appeared in Spain much later than in most Western European countries. In France and Switzerland, which were precursors of this type of social mobility, it started to flourish already in the 50 -ties of the $20^{\text {th }}$ century. In the 60 -ties, the idea of rural tourism was implemented in Austria, Ireland, Great Britain and Italy. The first stage of the rural tourism movement in Spain dates back to 1967. However, it was only in the late 90-ties that this trend reached the autonomous community of Castilla-La Mancha. (Vera 1997; Skoczek 2003)

1 The author was exploring the rural areas of Castilla-La Mancha during a six-month scholarship as part of the Socrates Erasmus Programme in the Ciudad Real Province. 
The autonomous community of Castilla-La Mancha, situated in the heart of the Iberian Peninsula, is perceived in a very specific way. The landform of this area is often believed to be monotonous and dull. The natural environment and cultural heritage of the region tend to be underestimated. These common misconceptions discourage many tourists from visiting Castilla-La Mancha.

Activation of countryside tourism in Castilla-La Mancha was meant as a tool for resuscitation of its rural areas. Due to the migration movements in the second half of the $20^{\text {th }}$ century the region suffered from a serious economic, social and cultural crisis. Thanks to rural tourism, the Castilian countryside received an opportunity for advancement. Autonomous authorities together with the community showed much commitment to the development of local tourist activity in order to improve the social and economic situation of the area. The European Community initiative LEADER and the Spanish Operational Programme PRODER, together with the help of the local community, have contributed to the dynamic development of rural tourism, despite (or because) of the fact that the process started much later than in other regions of the country. (Abellán Cebrián 2001; Skoczek 2003)

As for today, tourist industry in the rural areas of Castilla-La Mancha plays a complementary role to agricultural activity and urban tourism. Two of the most valuable historical sites of the region are the towns of Toledo and Cuenca, both listed by UNESCO as World Heritage sites. They constitute a popular target for foreign visitors as well as for domestic weekend tourists. The rural tourism industry in Castilla-La Mancha does not aim to compete with the urban tourist industry and, in fact, these two types of tourist activity do not interfere with each other.

An important feature of tourism in the rural areas is that it is almost exclusively shaped by the domestic tourist movement. Foreign tourists constitute a small percentage of all visitors and their number fluctuates.

The above observations are reflected in table 1 . As indicated in the table, the number of domestic tourists exceeds the number of foreign ones. In the period of 2001-2006, a stable increase of the total number of tourists visiting rural areas of Castilla-La Mancha was recorded. The number of domestic tourists grew steadily, whereas the number of foreign tourists differed from season to season. In general, the increase of the number of foreign tourists was more dynamic. However, 
in regard to statistics, the number of foreign tourists was very limited and had no significant influence on the current tendency. In 2004 and 2006 , the number of foreign visitors decreased.

Table 1.

Number of domestic and foreign tourists in rural accommodation facilities in Castilla-La Mancha in the period of 2001-2006

\begin{tabular}{|c|c|c|c|c|c|c|}
\hline Tourists & 2001 & 2002 & 2003 & 2004 & 2005 & 2006 \\
\hline Total & 58321 & 76783 & 82534 & 87573 & 103648 & 120969 \\
\hline Domestic & 57439 & 75440 & 80403 & 85954 & 100539 & 118604 \\
\hline Foreign & 882 & 1343 & 2131 & 1619 & 3109 & 2365 \\
\hline
\end{tabular}

Source: Own study based on INE 2006

A positive phenomenon is that, over the last few years, the number of tourists looking for accommodations in rural tourist facilities has been rising. Along with the development of accommodation facilities in rural areas the number of staff employed is also increasing.

Before 1994, there were only 8 accommodation facilities in the rural areas of Castilla-La Mancha, all of them located in the Cuenca Province. This meager offer reflected underdevelopment of the tourist industry in rural areas of the region.



Fig. 1. Increase of the number of rural accommodation facilities in Castilla-La Mancha in the period of $1995-2005$

Source: Own study based on IES 2006 
In 1995 (Fig.1.), there were 31 rural accommodation facilities in Castilla-La Mancha. In only one year this figure doubled. Since then, the number of rural accommodation facilities was on the increase. At the turn of 2004/2005, a record number of 139 new accommodation facilities was achieved. To reassume, in the decade of 1995-2005, rural accommodation facilities in Castilla-La Mancha developed in an abrupt and dynamic manner. The number of accommodation facilities increased 28 -fold in comparison to 1995 . At the end of 2005 there were 867 such objects.

A growing number of rural accommodation facilities had a positive impact on the quality of services offered. A simultaneous increase in the number of lodgings and improvement of service standards belongs to the priorities of the local government. (Sancho Comíns 2004)

What characterizes tourism in rural areas are short, in average 2.5-day stays, usually during the holiday season, on weekends or festive days.

Table 2.

Occupancy ratio [\%] in rural accommodation facilities on weekends and yearly in the period of 2003-2006

\begin{tabular}{|c|c|c|c|c|}
\hline & 2003 & 2004 & 2005 & 2006 \\
\hline Weekends & 30,8 & 28,9 & 28,8 & 29,6 \\
\hline Total & 14,7 & 14,5 & 14,4 & 14,4 \\
\hline
\end{tabular}

Source: Own study based on IET 2006

It is worth mentioning that the occupancy ratio in rural accommodation facilities on weekends accounts for $30 \%$ of the total annual occupancy and is twice as high as the yearly ratio, accounting for only $15 \%$ (Table 2.).

In the case of foreign tourists, the average length of stay (Table 3.) was subject to some fluctuations. However, majority of them stayed longer than 3 days. It means that foreign tourists visiting rural areas tend stay longer than domestic tourists, who due to their number, have stronger influence on the average length of stay ratio.

The tourist movement in rural areas of Castilla-La Mancha mainly has a local character. The majority of national tourists visiting the region come from the neighbouring communities of Madrid, Valencia and Murcia. 
Table 3.

Average length of stay of domestic and foreign tourists in rural accommodation facilities in the period of 2001-2006

\begin{tabular}{|c|c|c|c|}
\hline & Average & Domestic & Foreign \\
\hline 2001 & 2,55 & 2,53 & 3,82 \\
\hline 2002 & 2,39 & 2,37 & 3,60 \\
\hline 2003 & 2,47 & 2,48 & 2,21 \\
\hline 2004 & 2,66 & 2,63 & 4,0 \\
\hline 2005 & 2,54 & 2,51 & 3,64 \\
\hline 2006 & 2,50 & lack of data & lack of data \\
\hline
\end{tabular}

Source: Own study based on INE 2006

Castilla-León and Cataluna have the most powerful rural tourism industry in the country. The autonomous community of Castilla-León has launched an intensive advertising campaign internally and outside the borders of Spain, promoting its image as a well established rural tourism area. The undeniable success of this region should serve as an example for the authorities of Castilla-La Mancha. In its most prosperous year (2006), the number of visitors coming to Castilla-La Mancha constituted only 25\% of the tourists visiting Castilla-León. In comparison to other Spanish communities, the figures representing Castilla-La Mancha are also not remarkable. In the period of 1999-2006, it was usually ranked $10^{\text {th }}$ among 17 Autonomous Communities in regard to the number of tourists in rural areas.

It is worth underlining that rural tourism plays a very important function within the community of Castilla-La Mancha. First of all, it means diversification of the local economy. Agriculture is no longer the only source of income and low harvests do not entail financial hardship for the inhabitants.

Secondly, the development of rural tourism was one of the factors mitigating a long-time process of depopulation of the Castilian countryside. However, due to its specific character, work in the tourist industry is usually treated as an additional activity, complementary to other economic activities.

Another major role of tourism in the rural areas of Castilla-La Mancha is the creation of alternative employment opportunities for women who previously had problems with finding any extradomestic work.

The above premises lead to the conclusion that the tourist industry in rural areas is likely to continue its development because it generates measurable benefits for the local community. 
According to the author, the region of Castilla-La Mancha is well promoted on Internet, although advertising campaigns in other media are still insufficient. The local tourist industry should attempt to enter into new markets. It is recommended to allocate funds for international promotion of rural areas of Castilla-La Mancha. Castilla-León succeeded in attracting foreign tourists to discover its countryside. The region of Castilla-La Mancha has also much to be proud of: beautiful landscapes, natural environment, culture, traditions and historical heritage. The attractions list includes two national parks, five landscape parks as well as numerous natural reservations and monuments.

Exploring the rural areas of the region gives an impression of a journey into the past. Picturesque villages as well as friendly and hospitable people encourage tourists to visit the area. During her stay in Castilla-La Mancha, the author observed that many countryside lodgings have improved their service standards. Renovation of premises together with a good quality of service are a very positive phenomenon. On the other hand, they generate higher prices (for example: accommodation prices). This process may affect the number of tourists coming to the countryside. One of the main objectives of the local authorities is to preserve an alternative and less massive character of local tourism. However, if the high standard accommodation offer becomes too homogenous, it may have a curbing effect on the development of tourism in rural areas.

A serious problem and obstacle for development of international tourism, particularly youth oriented, is the poor condition of local transport infrastructure. Buses run rarely and not on all weekdays and at times, only seasonally. The issue of inefficient and irregular public transport cannot be underestimated as the region of CastillaLa Mancha spreads over a vast territory and the distances between different tourist sites are quite significant.

What is more, regions that are exceptionally attractive to tourists may face a conflict between the concept of tourism in rural areas (less massive, dispersed) and the temptation to evolve in the direction of rural tourism. The basic value of dispersed tourism in rural areas is related to its more individual character. On the other hand, it is understandable that local inhabitants strive to maximize their profits and therefore are interested in hosting an increasing numbers of visitors. It is possible to avoid this kind of a clash with the help of effective policies and interventions by the local authorities. A positive 
example of such a strategy was the introduction of accommodation limits in particular tourist facilities in rural areas.

The rural areas of Castilla-La Mancha are so extensive that there still is much capacity for development of the tourist industry without a threat to its individual and dispersed character.

\section{REFERENCES}

Abellán Cebrián F. 2001, El Turismo Rural en Castilla-La Mancha, [in:] Lecciones de Desarrollo Rural (ed. Pillet Capdepón F.), Edita Lozano Artes Graficas S.L., Ciudad Real, 219-225.

Sancho Comíns J., Panadero Moya M. 2004, Atlas del turismo rural de CastillaLa Mancha, Ed. Instituto Geográfico Nacional, Madrid.

Skoczek M. 2003, Turystyka wiejska jako czynnik ochrony dziedzictwa kulturowego w Hiszpanii i Portugalii [Rural tourism as a protective element of the natural heritage in Spain and Portugal; in Polish], Prace $i$ Studia Geograficzne, t. 32, ss. $35-48$.

Vera J.F. 1997, Análisis territorial del turismo. Una nueva geografía del turismo, Ariel, Barcelona.

Zwierzchowska J. 2007, Turystyka na obszarach wiejskich w Kastylii-La Manchy [Tourism in the rural areas of Castilla-LaMancha, in Polish], Wydział Geografii i Studiów Regionalnych, Uniwersytet Warszawski.

\section{Internet sources:}

Statistic:

http://www.ine.es, access: servicios, hostelería y turismo, 04-06-2007.

http://www.iet.tourspain.es, access: información estadistíca, 04-06-2007.

English translation: Małgorzata Miłaszewska 